\title{
An Analysis of Livelihood Security of Scheduled Caste (SC) Farmers through Integrated Farming System (IFS) in Bengaluru Urban District
}

\author{
V. L. Madhu Prasad ${ }^{1}$, Usha Ravindra ${ }^{2}$ and S. Sujay Kumar ${ }^{3 *}$ \\ ${ }^{1}$ FTI, UAS (B), ${ }^{2}$ Dept. of Food and Nutrition, $U A S(B),{ }^{3} U A S(B)$ \\ *Corresponding author
}

\begin{tabular}{l} 
Ke y w o r d s \\
$\begin{array}{l}\text { Integrated farming } \\
\text { system, Scheduled } \\
\text { caste and } \\
\text { Livelihood security }\end{array}$ \\
Article Info \\
$\begin{array}{l}\text { Accepted: } \\
\text { 22 November } 2020 \\
\text { Available Online: } \\
\text { 10 December } 2020\end{array}$ \\
\hline
\end{tabular}

\section{Keywords}

Integrated farming system, Scheduled caste and

Livelihood security

Article Info

Accepted:

Available Online:

ecember 2020

\section{A B S T R A C T}

The study was conducted in purposively selected three taluks of Bengaluru Urban district. Total sample of 242respondents were purposively selected for the study. The data were collected by using structured interview schedule and analyzed by using appropriate statistical tools. It was observed that livelihood security of respondents in less satisfied category decreased by 12.39 per cent, satisfied category decreased by 2.07 per cent and highly satisfied category improved by 14.46 per cent after implementation of the project. Out of seven dimensions of livelihood security maximum increase observed in employment security $(66.21 \%)$ followed by living amenities (65.57\%), economic efficiency $(51.08 \%)$, social equitability (44.16\%), ecological security $(39.12 \%)$, assets $(36.46 \%)$ and coping strategies against stress $(35.15 \%)$. Overall, 48.37 per cent increased after implementation of project. Livestock component generated 323mandays employment and provided additional net income of Rs. 68860 to beneficiary farmers. In 2018 reported that the average gross income of farmers increased to Rs. 118564 from both crop and livestock enterprises of IFS against Rs. 12062 before implementation of the project. In total farmers could realized Rs. 83807 net profit by adopting IFS. As such, farmers are getting 3.41 rupee income for every one rupee investment under IFS. The characteristics such as Cropping pattern, Innovativeness, Training undergone, Willingness towards IFS and Access to extension personnel exhibited positive and significant relationship with farmers livelihood security. Hence, the concerned development departments should organize the demonstrations, trainings, field days, exposure visits etc., to educate the farmers about IFS. The positive and significantly related characteristics need to be considered while selecting the farmers for the extension educational programmes to enhance their livelihood security.

\section{Introduction}

Agriculture has always been considered as the back- bone of our country. In India 58 per cent of rural population is engaged in agriculture and 80 per cent of population lives directly or indirectly on income derived from agriculture (Harshitha et al., 2018). The operational farm holding in India is declining and over 85 million out of 115 million are below the size of 1.00 ha (Manjunatha et al., 2014). Due to ever increasing population and decline in per capita availability of land in the country, practically there is no scope for 
horizontal expansion of land for agriculture. Only vertical expansion is possible by integrating farming components requiring lesser space and time and ensuring reasonable returns to farm families. The Integrated Farming System therefore assumes greater importance for sound management of farm resources to enhance the farm productivity and reduce the environmental degradation, improve the quality of life of resource poor farmers and maintain sustainability. There are 115 million operational holdings in the country and about 80 per cent are marginal and small farmers (Manjunatha et al., 2014). Most of the Scheduled Caste farmers comes under small and marginal category of land holding and agricultural labourers. The per capita land holding of SC farmers is 1.3 ha as against state average of 1.74 ha. These farmers are doing farming activity to fulfill the basic needs of house hold including food (cereal, pulses, oilseeds, milk, fruit, honey, meat, etc.), feed, fodder, fiber etc. But,t heir main focus was individual components but not in a integrated manner and this made attention about Integrated Farming System.

Efforts have been made at the ICAR and State Agricultural Universities level to increase the productivity of different components of farming system i.e. field crops, horticultural crops, live stock (dairy, goatry, piggery), poultry (chicken, ducks, quail, pigeons), apiculture, sericulture, mushroom cultivation, organic manures production, bio-gas etc. individually but lacking in their integration by following farming system approach. The integration is made in such a way that product of one component should be the input for other enterprises with high degree of complimentary effects on each other. The University of Agricultural Sciences, Bangalore implemented the project entitled "Livelihood Improvement of Scheduled Caste (SC) Farm Families through Integrated Farming System (IFS)" with the financial support from the Government of Karnataka under Scheduled Caste Sub Plan (SCSP) during the period from 2014-15- to 2018-19. The project aims at sustainable development of agriculture among SC farmers by bringing them to mainstream and also efficient management of soil, water, crop and IPM practices in crop husbandry. Further, it integrate dairy, poultry, sheep, piggery, fishery, sericulture, agro-forestry and other related enterprises with crop husbandry based on their needs which increases the overall net income. With this background, the present study is conceptualized to following objectives include to know the personal and socio-psychological characteristics of respondents. To measure the livelihood security of SC farmers practicing Integrated Farming System; To analyze the impact of Integrated Farming System on development of SC farmers; To know the relationship between personal and socio-psychological characteristics of respondents with their livelihood security.

\section{Materials and Methods}

The study was conducted in purposively selected Bengaluru Urban district of Karnataka based on the implementation of the project entitled "Livelihood Improvement of Scheduled Caste (SC) Farm Families through Integrated Farming System (IFS)". Three taluks namely Anekal, Bangalore North and Bangalore South were selected. Two Grama Panchayats from each taluk and 3 to 4 villages from each Grama Panchayat were selected based on maximum number of SC farm families. All the farm families having land holding 1 to 5 acres were considered as beneficiaries (respondents) under the project. Total sample of 242respondents were selected for the study. The data were collected by using structured interview schedule and analyzed using mean, percentage, standard deviation, correlation coefficient and regression coefficient. Livelihood security measured by using five point continuum scale 
developed by Mamathalakshmi (2013) with slight modification before and after implementation of the project.

\section{Results and Discussion}

It was observed in Table 1 indicates that the majority respondents belongs to medium level of education, land holding, cropping pattern, livestock possession, mass media exposure, extension participation, social participation, scientific orientation, training undergone, participation in development programme, willingness towards agriculture and access to extension personnel. This finding can be explained on the basis of the fact that the the rural social environment was the major cause for such trend. As the SC people are still traditional bound, they don't prefer to continue their children education, the distance of higher study centres from villages might have prevented the parents to encourage higher education to their children. Participation in extension activities and development programmes provided opportunities for them to improve their knowledge about IFS technologies and to be rational in decision making and in adoption of new technologies. Further, the villages have more number of social organisations such as Grama Panchayats, Taluk Panchayats, Farmer Co-operatives etc., might have made them to take part in it. Further, the government reservation policy in these organizations might have enhance their participation in social organizations. The above trend in cropping pattern and livestock possession are noticed because all respondents received inputs like improved seeds, planting material and livestock components like cow, sheeps and poultry birds through the project free of cost and got optimum production, productivity and net income. The study results were supported by the findings of Jayanta Roy (2012), Mamathalakshmi (2013), Rokonuzzaman (2013), Sujay Kumar (2018) and Harshitha (2018).
The study conferred that respondents belongs to high category of innovativeness, management orientation, risk orientation, level of aspiration and access to resources. High level of innovativeness, risk orientation, management orientation and level of aspiration due to the fact that most of the respondents were aware about new ideas, as they attend different training programs and field visits which were conducted by development departments and State Agricultural Universities which make opportunity to exploit the potentialities of IFS enterprises. Such individuals would be possessing more entrepreneurial characteristics like innovativeness, achievement motivation etc.Further, low level of cosmopoliteness. It could be due to the fact that the village does not had better road connectivity and transport facilities, which enabled the respondents not to visit city to sell their produce, to purchase inputs, to meet the officers of developmental departments / project staff to seek advice or to derive benefits as well as for domestic and entertainment purposes.

A critical appraisal of Table 2 indicates that the livelihood security of respondents in less satisfied category decreased by 12.39 per cent, satisfied category decreased by 2.07 per cent and highly satisfied category improved by 14.46 per cent after implementation of the project.

The data depicted in Table 3 indicates that out of seven dimensions of livelihood security maximum increase was observed in employment security(66.21\%) followed by living amenities $(65.57 \%)$, economic efficiency $(51.08 \%)$, social equitability (44.16\%), ecological security (39.12\%), assets $(36.46 \%)$ and coping strategies against stress (35.15\%). Overall, 48.37 per cent increase was observed after implementation of project (Fig. 1). 
Relationship between personal, psychological and socio-economic characteristics of respondents with their livelihood security

The findings in the Table 4 imply that five out of 18 characteristics found to have positive and significant relationship with livelihood security. The characteristics such as cropping pattern, innovativeness, training undergone, willingness towards IFS and access to extension personnel exhibited positive and significant relationship with farmers livelihood security. Cropping pattern and innovativeness had positive and significant relationship with livelihood security, the possible reasons might be farmers mainly depend on farming for their livelihood, increasing the cropping intensity gives better income. This in turn influences livelihood security of the respondents. The innovativeness of an individual is closely associated with change, adopting innovative ideas and practices leading to security for the life. The exposure of respondents to training increases their confidence level and skills to do varied works as a result earning also increases. Hence, training received positive and significant relationship with livelihood security of respondents. It is clear from the results that there was a positive and significant relationship between willingness in agriculture and livelihood security. As farmers mainly depend on farming, willingness to do agriculture, to utilization of available resources, which leads to higher productivity, profitability, generates employment and finally income of farm. This in turn influences livelihood security of respondents. The access to extension personnel of the respondents was found to be significantly correlated with their livelihood security. The respondents had regular contact with the agriculture officers, KVK scientists and farm scientists of UAS, Bangalore through project. Due to their regular contact with the extension professionals and benefit availed under the project to the respondents might have developed favourable attitude towards the IFS and other side improving their livelihood. The findings are in conformity with the results obtained by Mamathalakshmi (2013), Sujay Kumar (2018) and Harshitha (2018).

Table.1 Distribution of respondents according to their personal, social, economic and psychological variables

\begin{tabular}{|c|c|c|c|c|}
\hline Sl. No. & Variables & Category & Number & Per cent \\
\hline \multirow[t]{3}{*}{1.} & \multirow[t]{3}{*}{ Education } & Low & 48 & 19.83 \\
\hline & & Medium & 145 & 59.92 \\
\hline & & High & 49 & 20.25 \\
\hline \multirow[t]{3}{*}{2.} & \multirow[t]{3}{*}{ Land holding } & Marginal & 49 & 20.25 \\
\hline & & Small & 103 & 42.56 \\
\hline & & Big & 90 & 37.19 \\
\hline \multirow[t]{3}{*}{3.} & \multirow[t]{3}{*}{ Cropping pattern } & Low & 70 & 28.93 \\
\hline & & Medium & 101 & 41.74 \\
\hline & & High & 71 & 29.34 \\
\hline \multirow[t]{3}{*}{4.} & \multirow[t]{3}{*}{ Livestock possession } & Low & 82 & 33.88 \\
\hline & & Medium & 84 & 34.71 \\
\hline & & High & 76 & 31.40 \\
\hline \multirow[t]{2}{*}{5.} & \multirow[t]{2}{*}{ Cosmopoliteness } & Low & 89 & 36.78 \\
\hline & & Medium & 69 & 28.51 \\
\hline
\end{tabular}

$(\mathrm{N}=242)$ 


\begin{tabular}{|c|c|c|c|c|}
\hline & & High & 84 & 34.71 \\
\hline \multirow[t]{3}{*}{6.} & \multirow{3}{*}{ Innovativeness } & Low & 87 & 35.95 \\
\hline & & Medium & 64 & 26.45 \\
\hline & & High & 91 & 37.60 \\
\hline \multirow[t]{3}{*}{7.} & \multirow[t]{3}{*}{ Mass media exposure } & Low & 75 & 30.99 \\
\hline & & Medium & 98 & 40.50 \\
\hline & & High & 69 & 28.51 \\
\hline \multirow[t]{3}{*}{8.} & \multirow{3}{*}{$\begin{array}{l}\text { Extension } \\
\text { participation }\end{array}$} & Low & 70 & 28.93 \\
\hline & & Medium & 102 & 42.15 \\
\hline & & High & 70 & 28.93 \\
\hline \multirow[t]{3}{*}{9.} & \multirow[t]{3}{*}{ Social participation } & Low & 64 & 26.45 \\
\hline & & Medium & 108 & 44.63 \\
\hline & & High & 70 & 28.93 \\
\hline \multirow[t]{3}{*}{10.} & \multirow[t]{3}{*}{ Scientific orientation } & Low & 63 & 26.03 \\
\hline & & Medium & 96 & 39.67 \\
\hline & & High & 83 & 34.30 \\
\hline \multirow[t]{3}{*}{11.} & \multirow{3}{*}{$\begin{array}{l}\text { Management } \\
\text { orientation }\end{array}$} & Low & 78 & 32.23 \\
\hline & & Medium & 75 & 30.99 \\
\hline & & High & 89 & 36.78 \\
\hline \multirow[t]{3}{*}{12.} & \multirow{3}{*}{ Level of aspiration } & Low & 70 & 28.93 \\
\hline & & Medium & 73 & 30.17 \\
\hline & & High & 99 & 40.91 \\
\hline \multirow[t]{3}{*}{13.} & \multirow[t]{3}{*}{ Risk orientation } & Low & 74 & 30.58 \\
\hline & & Medium & 79 & 32.64 \\
\hline & & High & 89 & 36.78 \\
\hline \multirow[t]{3}{*}{14.} & \multirow[t]{3}{*}{ Training undergone } & Low & 74 & 30.58 \\
\hline & & Medium & 126 & 52.07 \\
\hline & & High & 42 & 17.36 \\
\hline \multirow[t]{3}{*}{15.} & \multirow{3}{*}{$\begin{array}{l}\text { Participation in the } \\
\text { developmental } \\
\text { programme }\end{array}$} & Low & 49 & 20.25 \\
\hline & & Medium & 140 & 57.85 \\
\hline & & High & 53 & 21.90 \\
\hline \multirow[t]{3}{*}{16.} & \multirow{3}{*}{$\begin{array}{l}\text { Willingness towards } \\
\text { IFS }\end{array}$} & Low & 75 & 30.99 \\
\hline & & Medium & 94 & 38.84 \\
\hline & & High & 73 & 30.17 \\
\hline \multirow[t]{3}{*}{17.} & \multirow{3}{*}{$\begin{array}{l}\text { Access to extension } \\
\text { personnel }\end{array}$} & Low & 65 & 26.86 \\
\hline & & Medium & 105 & 43.39 \\
\hline & & High & 72 & 29.75 \\
\hline \multirow[t]{3}{*}{18.} & \multirow[t]{3}{*}{ Access to resources } & Low & 70 & 28.93 \\
\hline & & Medium & 84 & 34.71 \\
\hline & & High & 88 & 36.36 \\
\hline
\end{tabular}


Table.2 Distribution of SC farmers practicing IFS according to their livelihood security

\begin{tabular}{|l|l|c|c|c|c|c|}
\hline \multirow{2}{*}{ Sl. No. } & \multirow{2}{*}{ Category } & \multicolumn{2}{|c|}{ Before } & \multicolumn{2}{c|}{ After } & Change in Per cent \\
\cline { 3 - 7 } & & Number & Per cent & Number & Per cent & \\
\hline & Less satisfied & 107 & 44.21 & 77 & 31.82 & -12.39 \\
\hline & Satisfied & 80 & 33.06 & 75 & 30.99 & -2.07 \\
\hline & Highly Satisfied & 55 & 22.73 & 90 & 37.19 & 14.46 \\
\hline & Total & 242 & 100.00 & 242 & 100.00 & \\
\hline
\end{tabular}

Table.3 Dimension-wise analysis of livelihood security pattern among respondents

\begin{tabular}{|c|l|c|c|c|}
\hline \multirow{2}{*}{ SI. No. } & \multicolumn{1}{|c}{ Dimension } & \multicolumn{2}{c|}{ Mean Value } & \multirow{2}{*}{ \% increase } \\
\cline { 3 - 4 } & & Before & After & \\
\hline $\mathbf{1}$ & Assets & 960 & 1310 & 36.46 \\
\hline $\mathbf{2}$ & Living amenities & 822 & 1361 & 65.57 \\
\hline $\mathbf{3}$ & Economic efficiency & 415 & 627 & 51.08 \\
\hline $\mathbf{4}$ & Ecological security & 588 & 818 & 39.12 \\
\hline $\mathbf{5}$ & Social equitability & 634 & 914 & 44.16 \\
\hline $\mathbf{6}$ & Coping strategies against stress & 660 & 892 & 35.15 \\
\hline $\mathbf{7}$ & Employment security & 728 & 1210 & 66.21 \\
\hline & Overall Livelihood Security & 4807 & 7132 & 48.37 \\
\hline
\end{tabular}

Table.4 Relationship between characteristics of respondents with their livelihood security

\begin{tabular}{|r|l|c|}
\hline Sl. No. & \multicolumn{1}{|c|}{ Independent variables } & $(\mathrm{N}=242)$ \\
\hline $\mathbf{1 .}$ & Education & -0.041 \\
\hline $\mathbf{2 .}$ & Land holding & -0.015 \\
\hline $\mathbf{3 .}$ & Cropping pattern & $0.169^{* *}$ \\
\hline $\mathbf{4 .}$ & Livestock possession & 0.047 \\
\hline $\mathbf{5 .}$ & Csmopoliteness & -0.085 \\
\hline $\mathbf{6 .}$ & Innovativeness & $0.353^{* *}$ \\
\hline $\mathbf{7 .}$ & Mass media exposure & -0.104 \\
\hline $\mathbf{8 .}$ & Extension participation & 0.103 \\
\hline $\mathbf{9 .}$ & Social participation & 0.053 \\
\hline $\mathbf{1 0 .}$ & Scientific orientation & -0.007 \\
\hline $\mathbf{1 1}$. & Management orientation & 0.0176 \\
\hline $\mathbf{1 2 .}$ & Level of aspiration & 0.124 \\
\hline $\mathbf{1 3}$. & Risk orientation & 0.018 \\
\hline $\mathbf{1 4}$. & Training undergone & $0.337^{* *}$ \\
\hline $\mathbf{1 5}$. & Participation in the developmental programme & 0.039 \\
\hline $\mathbf{1 6 .}$ & Willingness towards IFS & $0.204^{* *}$ \\
\hline $\mathbf{1 7 .}$ & Access to extension personnel & $0.260^{* *}$ \\
\hline $\mathbf{1 8}$ & Access to resources & 0.124 \\
\hline
\end{tabular}

NS: Non-Significant; *: Significant at 5\% level; **: Significant at $1 \%$ level. 
Table.5 Multiple regression analysis of characteristics of respondents with their livelihood security

\begin{tabular}{|c|c|c|c|c|}
\hline $\begin{array}{l}\text { Sl. } \\
\text { No }\end{array}$ & Variables & $\begin{array}{l}\text { Regression } \\
\text { coefficient } \\
\text { (b) }\end{array}$ & $\begin{array}{l}\text { Std. Error of } \\
\text { regression } \\
\text { co-efficient }\left(\mathrm{SE}_{\mathbf{b}}\right)\end{array}$ & 't' value \\
\hline 1 & Education & -.013 & .254 & -.050 \\
\hline 2 & Land holding & 247 & .493 & .501 \\
\hline 3 & Cropping pattern & .060 & .028 & $2.095^{*}$ \\
\hline 4 & Livestock possession & -.023 & .067 & -.345 \\
\hline 5 & Cosmopoliteness & -.023 & .157 & -.148 \\
\hline 6 & Innovativeness & .526 & .150 & $3.510 * *$ \\
\hline 7 & Mass media exposure & -.077 & .137 & -.564 \\
\hline 8 & Extension participation & .315 & .148 & $2.127^{*}$ \\
\hline 9 & Social participation & .023 & .091 & .250 \\
\hline 10 & Scientific orientation & -.173 & .119 & -1.451 \\
\hline 11 & Management orientation & -.331 & .099 & $-3.353 * *$ \\
\hline 12 & Level of aspiration & .046 & .079 & .587 \\
\hline 13 & Risk orientation & -.015 & .088 & -.172 \\
\hline 14 & Training undergone & .967 & .267 & $3.616^{* *}$ \\
\hline 15 & $\begin{array}{l}\text { Participation in the developmental } \\
\text { programme }\end{array}$ & .200 & .340 & .588 \\
\hline 16 & Willingness towards IFS & .004 & .086 & .051 \\
\hline 17 & Access to extension personnel & .290 & .080 & $3.631 * *$ \\
\hline 18 & Access to resources & .082 & .066 & 1.234 \\
\hline
\end{tabular}


Table.6 Economic analysis of Integrated Farming System (IFS) components before and after implementation of project

\begin{tabular}{|c|c|c|c|c|c|c|c|c|c|c|c|c|c|c|c|c|c|c|c|c|c|}
\hline \multirow[b]{2}{*}{$\begin{array}{c}\text { Crop } \\
\text { Component }\end{array}$} & \multirow[b]{2}{*}{$\begin{array}{l}\text { Avg. } \\
\text { Land } \\
\text { Holding } \\
\text { (Acre.) }\end{array}$} & \multicolumn{8}{|c|}{ Before } & \multicolumn{8}{|c|}{ After } & \multirow{2}{*}{$\begin{array}{c}\text { Change } \\
\text { in yield } \\
(\%)\end{array}$} & \multirow{2}{*}{$\begin{array}{l}\text { Change } \\
\text { in } \\
\text { Income } \\
(\%)\end{array}$} & \multirow{2}{*}{$\begin{array}{c}\text { Emply. Gene. } \\
\text { in } \\
\text { (Mandays/ac.) }\end{array}$} & \multirow{2}{*}{$\begin{array}{l}\text { Emply. } \\
\text { Gene. of } \\
\text { Beneficiary } \\
\text { farmers } \\
\text { (Mandays) }\end{array}$} \\
\hline & & $\begin{array}{l}\text { Avg. } \\
\text { Yield } \\
\text { (Ql./ac.) }\end{array}$ & $\begin{array}{l}\begin{array}{c}\text { Avg. yield } \\
\text { of } \\
\text { Beneficiary } \\
\text { farmers } \\
\text { (Q1./ac.) }\end{array} \\
\end{array}$ & $\begin{array}{c}\text { Price } \\
\text { (Rs./Ql.) }\end{array}$ & $\begin{array}{l}\text { Prod. } \\
\text { Cost/ac. } \\
\text { (Rs.) }\end{array}$ & $\begin{array}{c}\text { Prod. Cost } \\
\text { of } \\
\text { Beneficiary } \\
\text { farmers(Rs.) }\end{array}$ & $\begin{array}{c}\text { Gross } \\
\text { Income } \\
\text { (Rs./ac.) }\end{array}$ & $\begin{array}{c}\text { Net } \\
\text { Income } \\
\text { (Rs./ac.) }\end{array}$ & $\begin{array}{l}\text { B:C } \\
\text { Ratio }\end{array}$ & $\begin{array}{l}\text { Avg. } \\
\text { Yield } \\
\text { (Ql./ac.) }\end{array}$ & 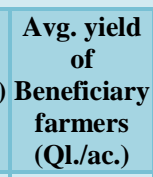 & $\begin{array}{c}\text { Price } \\
\text { (Rs./Ql.) }\end{array}$ & $\begin{array}{l}\text { Prod. } \\
\text { Cost/ac. } \\
\text { (Rs.) }\end{array}$ & $\begin{array}{c}\text { Prod. Cost } \\
\text { of } \\
\text { Beneficiary } \\
\text { farmers(Rs.) }\end{array}$ & \begin{tabular}{|l|} 
Gross \\
Income \\
(Rs./ac.)
\end{tabular} & $\begin{array}{c}\text { Net } \\
\text { Income } \\
\text { (Rs./ac.) }\end{array}$ & $\begin{array}{c}\text { B:C } \\
\text { Ratio }\end{array}$ & & & & \\
\hline Ragi (n1=139) & 0.66 & 5.50 & 3.63 & 1550.00 & 5800.00 & 3828.00 & 8525.00 & 4697.00 & 2.23 & 9.00 & 5.94 & 1900.00 & 7500.00 & 4950.00 & 11286.00 & 6336.00 & 2.28 & 63.64 & 32.39 & 85.00 & 56.10 \\
\hline Maize (n2=103) & 0.45 & 6.00 & 2.70 & 1310.00 & 3250.00 & 1462.50 & 3537.00 & 2074.50 & 2.42 & 9.50 & 4.28 & 1425.00 & 5500.00 & 2475.00 & 6091.88 & 3616.88 & 2.46 & 58.33 & 72.23 & 66.00 & 29.70 \\
\hline Redgram* & & & & & & & & & & 1.50 & 1.67 & 3800.00 & 1200.00 & 1332.00 & 6327.00 & 4995.00 & 4.75 & & & 6.00 & 6.66 \\
\hline Total & & & & & & 5290.50 & 12062.00 & 6771.50 & 2.28 & & & & & 8757.00 & 23704.88 & 14947.88 & 2.71 & & 96.53 & & 92.46 \\
\hline $\begin{array}{c}\text { Livestock } \\
\text { Component }\end{array}$ & \multicolumn{2}{|c|}{$\begin{array}{l}\text { Body live wt. or } \\
\text { Ltrs/ sheep or } \\
\text { poultry or pig or } \\
\text { cow }\end{array}$} & \multicolumn{2}{|c|}{ Price/kg or Ltr } & & Cost & $\begin{array}{c}\text { Gross } \\
\text { Income } \\
\text { (Rs.) }\end{array}$ & $\begin{array}{c}\text { Net } \\
\text { Income } \\
\text { (Rs.) }\end{array}$ & $\begin{array}{l}\text { B:C } \\
\text { Ratio }\end{array}$ & \multicolumn{2}{|c|}{$\begin{array}{l}\text { Body live wt. or } \\
\text { Ltrs/ sheep or } \\
\text { poultry or pig or } \\
\text { cow }\end{array}$} & \multicolumn{2}{|c|}{ Price/kg or Ltr } & Cost & $\begin{array}{c}\text { Gross } \\
\text { Income } \\
\text { (Rs.) }\end{array}$ & $\begin{array}{c}\text { Net } \\
\text { Income } \\
\text { (Rs.) }\end{array}$ & $\begin{array}{c}\text { B:C } \\
\text { Ratio }\end{array}$ & $\begin{array}{c}\text { Change } \\
\text { in yield } \\
(\%)\end{array}$ & $\begin{array}{l}\text { Change } \\
\text { in } \\
\text { Income } \\
(\%)\end{array}$ & $\begin{array}{l}\text { Emply. Gene. } \\
\text { (Mandays) }\end{array}$ & $\begin{array}{l}\text { Emply. } \\
\text { Gene. of } \\
\text { Beneficiary } \\
\text { farmers } \\
\text { (Mandays) }\end{array}$ \\
\hline Cow $(n 1=130)$ & & & & & & & & & & 1620.00 & & 28.00 & & 17000.00 & 45360.00 & 28360.00 & 2.67 & & & & 228.00 \\
\hline Sheep $(\mathrm{n} 2=112)$ & & & & & & & & & & 120.00 & & 400.00 & & 9000.00 & 48000.00 & 39000.00 & 5.33 & & & & 95.00 \\
\hline Poultry*(n3=160) & & & & & & & & & & 10.00 & & 150.00 & & & 1500.00 & 1500.00 & & & & & \\
\hline Total & & & & & & & & & & & & & & 26000.00 & 94860.00 & 68860.00 & 3.65 & & & & 323.00 \\
\hline Grand total & & & & & & 5290.50 & 12062.00 & 6771.50 & 2.28 & & & & & 34757.00 & 118564.88 & 83807.88 & 3.41 & & 96.53 & & 415.46 \\
\hline
\end{tabular}


Fig.1 Income from crop component before and after implementation of project

\section{Before}
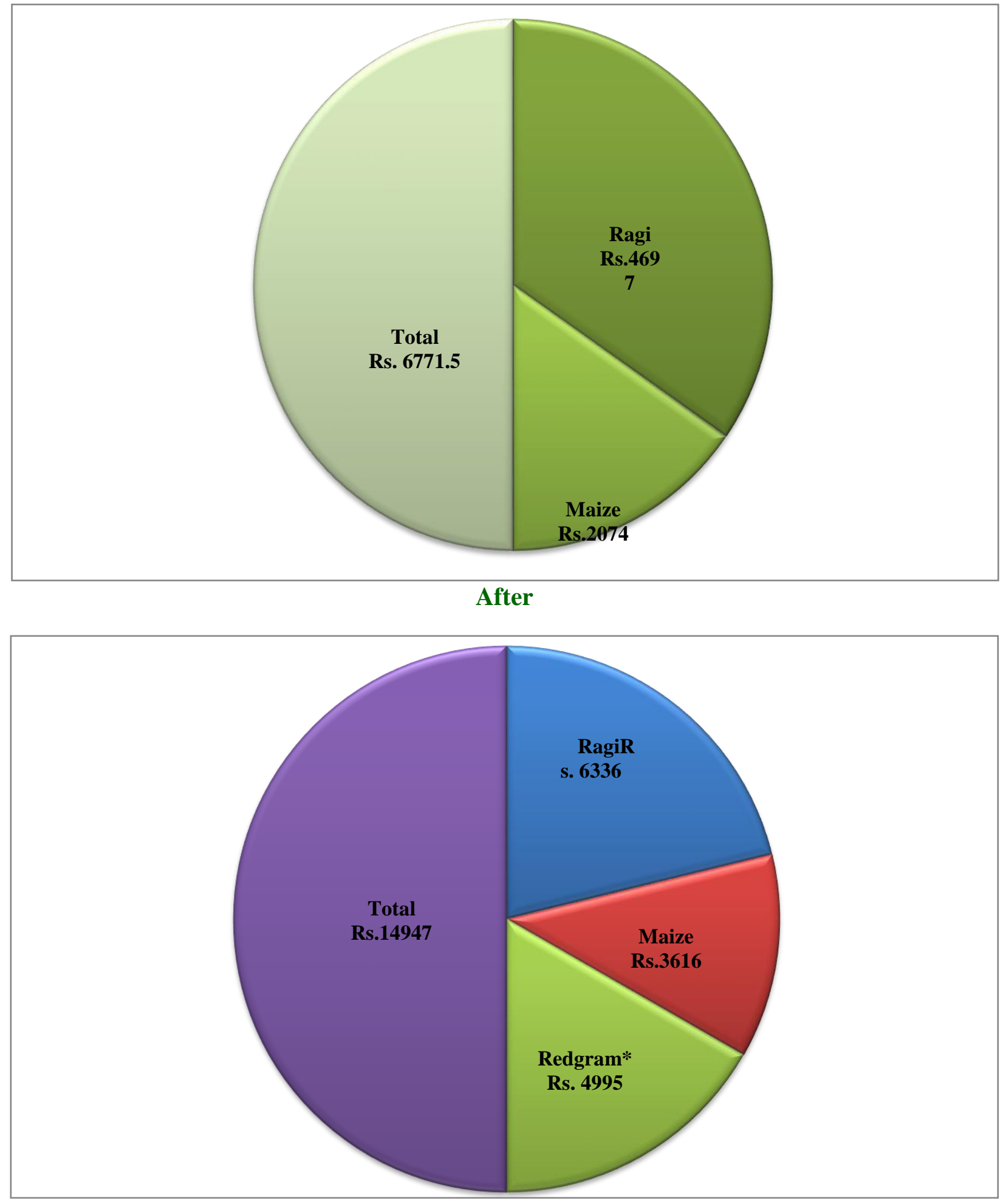
Extent of contribution of personal, psychological and socio-economic characteristics to livelihood security of respondents

The regression test was applied to ascertain the contribution of independent variables to the livelihood security of respondents and the results are presented in Table 5. The results of multiple linear regression analysis showed that variables such as cropping pattern, innovativeness, extension participation, management orientation, training undergone and access to extension personnel had significantly contributed. The R2 value of 0.313 indicated that all 18 variables had contributed to the tune of 31.3 per cent of variation in livelihood security. The possible reasons might be that the personal and sociopsychological variables of respondents are the deciding factors of their livelihood security. These characteristics have synergic effects to one another, helping each other to have a major extent of contribution to the livelihood security. The findings are in conformity with the results obtained by Sujay Kumar (2018) and Harshitha et al., (2018).

\section{Income of respondents after} implementation of project

Data presented in Table 6 indicates that, after implementation of the project, the average yield of ragi and maize increased to 63.64 per cent and 58.33 per cent, respectively. The livestock component such as cow, sheep and backyard poultry and redgram as intercrop along with ragi and maize were introduced under the IFS project. Livestock component generated 323mandays employment and provided additional net income of Rs. 68860 to beneficiary farmers. In 2018 reported that the average gross income of farmers increased to Rs. 118564 from both crop and livestock enterprises of IFS against Rs. 12062 before implementation of the project. In total he could realize about Rs. 83807 net profit by adopting IFS in their farm. As such, they are getting 3.41 rupee income for every one rupee investment under IFS. Similar results reported by Uddin (2015) and Kamble Anand Shankar et al., (2017).

In conclusion, the findings of the study revealed that the livelihood security improved from less satisfied to highly satisfied level $(14.46 \%)$, out of seven dimensions of livelihood security maximum increase was noticed in employment security (66.21\%). Further, respondents earned Rs.3.41 income for every one rupee investment under IFS. The characteristics such as cropping pattern, innovativeness, management orientation, training undergone, willingness towards IFS and access to extension personnel exhibited positive and significant relationship. Hence, encourage the farmers to practice IFS which helps to increase their livelihood by organising extension educational programmes by the concerned development organisations. Further, they should give more emphasis towards amplification of these characteristics to enhance livelihood security of farmers practicing IFS.

\section{References}

Harshitha, D., 2018. Family Farming Efficiency and Livelihood security of women headed Households in Tumakuru district. Ph.D. Thesis, Univ. Agric. Sci., Bangalore.

Harshitha, D., Madhu Prasad, V. L. and Sanjay Yadav, 2018. Correlates of livelihood Security of women headed households practicing family farming in Tumakuru district. Internatl. J. Agric. Sci., 15:6810-6812.

Jayanta Roy, 2012. Impact analysis of Mahatma Gandhi National Rural Employment Guarantee programme in Dhalai district of Tripura. M. Sc. (Agri.) 
Thesis, Univ. Agric. Sci., Bangalore. Mamathalakshmi, N., 2013. An analysis of livelihood security among agricultural labourers in Karnataka. Ph.D. Thesis, Univ. Agric. Sci.,Bangalore.

Manjunatha S.B., Shivmurthy D., Sunil A Satyareddi, Nagaraj M.V., Basavesha K.N. 2014. Integrated Farming System An Holistic Approach: A Research and Reviews: J. Agric. Allied Sci. 4(3): 3038.

Rokonuzzaman, M., 2013, Training Needs of Tribal People Regarding Income Generating Activities. Indian Res. J. Extn. Edu., 13(2): 10-16.

Kamble Anand Shankar, L. N. Yogeesh, S.
M. Prashant, P. Sheik Peer and B.K. Desai, 2017, Integrated Farming System: Profitable Farming to Small Farmers. Internatl. J. Curr. Microbiol. App. Sci., 6(10): 2819-2824.

Sujay Kumar, S., 2018. Analysis of integrated farming system (IFS) on the development of Schedule Caste (SC) Farmers in Southern Karnataka. Ph.D. Thesis, Univ. Agric. Sci., Bangalore.

Uddin, M. T., Khan, M. A. and Islam, M. M., (2015), Integrated Farming and its Impact on Farmers' Livelihood in Bangladesh. Saarc J. Agri., 13(2):6179.

\section{How to cite this article:}

Madhu Prasad, V. L., Usha Ravindra and Sujay Kumar, S. 2020. An Analysis of Livelihood Security of Scheduled Caste (SC) Farmers through Integrated Farming System (IFS) in Bengaluru Urban District. Int.J.Curr.Microbiol.App.Sci. 9(12): 2963-2973. doi: https://doi.org/10.20546/ijcmas.2020.912.351 